\title{
Isolation and characterization of some multi-antibiotic resistant bacterial pathogens associated with nosocomial infections
}

\author{
Zakaria A. Baka, Mohamed I. Abou Dobara, Ahmed K. A. El-Sayed, Shimaa A. Badawy* \\ Botany Department, Faculty of Science, Damietta University, Damietta, Egypt
}

Received: 08 December 2013 / Accepted: 05 February 2014

* Corresponding author: (Fax: +20.57.2403868, email: shimaa_a_badwy@yahoo.com)

\begin{abstract}
Nosocomial infections are frequent complications of hospitalization, caused by opportunistic pathogens that gain access to hosts undergoing invasive procedures. This study was carried out to investigate the presence of antibiotic resistance bacteria from hospital environment of Damietta, Egypt. Two hundred and six clinical bacterial isolates were collected from different samples (sink, floor, bed, bed cover, toilet floor, bed pan, ward wall and hospital staff apparel (protective gowns, hand groves and face-shield) within reception hall, maternity ward, convalescing wards, surgical theaters, intensive care, dental unit, pharmacy and laboratory) from (Kafr Saad General Hospital and El-Azhar University Teaching Hospital). Four bacterial species were identified as Bacillus subtilis, Bacillus cereus, Klebsiella pneumoniae and Enterobacter aerogenes using standard morphological, biochemical tests and sequencing of 16S rRNA gene. Eleven antibiotics (Trimethoprim/sulphamethoxazole (25 $\mu \mathrm{g})$; Rifampicin (5 $\mu \mathrm{g})$; Piperacillin/tazobactam (110 $\mu \mathrm{g})$; Ofloxacin $(5 \mu \mathrm{g})$; Nitrofurantoin $(300 \mu \mathrm{g})$; Imipenem $(10 \mu \mathrm{g})$; Gentamicin $(120 \mu \mathrm{g})$; Ceftriaxone $(30 \mu \mathrm{g})$; Cefotaxime $(30 \mu \mathrm{g})$; Amikacin $(30 \mu \mathrm{g})$ and Amoxicillin/clavulanic acid $(30 \mu \mathrm{g})$ were tested against the bacterial isolates using disc diffusion method to determine the multi-drug resistance bacteria. Imipanem was found to be as the most effective drug against Klebsiella pneumoniae while ofloxacin, amikacin, piperacillin/tezobactam, gentamicin and rifampcin had low effect against Klebsiella pneumoniae and no effect of amoxicillin/clavulanic acid, cefotaxime, ceftriaxone, nitrufurantion and trimethoprim/sulehamethoxazole was recorded against Bacillus subtilis.
\end{abstract}

Keywords: multi-antibiotic resistant, nosocomial infections, Bacillus subtilis, Bacillus cereus, Klebsiella pneumoniae and Enterobacter aerogenes

\section{Introduction}

Nosocomial or hospital-acquired infections are usually defined as infections that are identified at least 48-72 hours following admission to health institutions [1]. Nosocomial infections are also important public health problems in developing countries as well as in developed countries [2]. The most frequent types of nosocomial infections are urinary tract infections (UTIs), surgicalwound infection, pneumonia, and bloodstream infections (BSIs) [3]. Nosocomial infections are 
caused by bacteria, viruses and fungi contracted by the contaminated equipment of the hospital. Many of the organisms associated with hospitalacquired infections exhibit two particular features: firstly, they are pathogens of wellestablished medical importance and secondly, they can withstand the severity or harshness of the hospital environment. The common bacterial pathogens present in the BSIs and UTIs are Staphylococcus aureus, Coagulase Negative Staphylococci (CoNS), Pseudomonas aeruginosa, Klebsiella pneumoniae, Escherichia coli, Enterobacter sp., Enterococcus sp., and Acinetobacter spp. [4]. As the result of extensive uses of antimicrobial agents, nosocomial pathogens have shifted away from easily treatable bacteria towards more resistant bacteria. This change is important problem for nosocomial infection control and prevention [5]. Nosocomial infections comprise one of the leading causes of preventable injuries and deaths in hospitals, affecting $5 \%$ to $10 \%$ of hospitalized patients and contributing to increased morbidity, mortality, length of stay and cost [6].

Enterobacter species are among the most common causes of gram-negative health careassociated infections, causing $8 \%$ of nosocomial bacteremia cases, and are the second most common gram-negative pathogens causing pneumonia in patients admitted to intensive care units (ICUs) [7]. In addition, in recent years, they are an increasing cause of community-acquired infections as well [7]. Resistance to a variety of broad-spectrum antimicrobials among Enterobacter strains, including $\beta$-lactams, is frequently encountered. Moreover, the emergence of resistance to extended-spectrum cephalosporins occurs often during therapy [8].

Nosocomial Klebsiella infections are caused mainly by Klebsiella pneumoniae, the medically most important species of the genus. To a much lesser degree, Klebsiella oxytoca has been isolated from human clinical specimens. It is estimated that Klebsiella sp. causes $8 \%$ of all nosocomial bacterial infections in the United States and in Europe. No great geographical variations in frequency have been noted. Klebsiella accounts for 3 to $7 \%$ of all nosocomial bacterial infections, placing them among the eight most important infectious pathogens in hospitals [9].

Bacillus species have been reported to cause bacteremia, endocarditis, pneumonia, meningitis, and other invasive infections, particularly in immunocompromised patients [10]. However, due to the wide distribution of Bacillus spores in nature (in soil, dust, water, and other animal sources) and in the hospital environment, this organism is usually considered a saprophyte or contaminant when detected in clinical specimens of different sources [10]. Dissemination of Bacillus species among hospitalized patients has previously been reported [11]. Most of these events were later considered nosocomial pseudoepidemics and were frequently secondary to the contamination of equipment and environments such as a fiber-optic bronchoscope, an air filtration system, a ventilator, a water bath, and a radiometric blood culture analyzer in microbiology laboratories [12].

Bacillus subtilis is an aerobic, spore-forming bacterium with soil as its natural habitat. It belongs to the family Bacillaceae but unlike its relatives Bacillus cereus and Bacillus anthracis it is not pathogenic. The bacterium has served as a model organism for the Gram positive order for the past 50 years and its biochemistry, genetics and physiology has been extensively mapped. The genome of $B$. subtilis strain 168 was completely sequenced in 1997 [13].

Bacillus cereus is a ubiquitous, gram-positive, endospore-forming rod. Occasionally, it can cause wound infection, gastrointestinal infection, pneumonia, meningitis, septicemia or food poisoning [14]. Intraocular infections caused by Bacillus cereus are very rare, and most cases are related to trauma [15]. In several case series, vision outcomes were uniformly poor, with $75 \%-$ $91 \%$ of patients experiencing a loss of light perception, eyeball evisceration, or enucleation [10]. Serious infections caused by bacteria that have become resistant to commonly used antibiotics have become a major global healthcare problem in the $21^{\text {th }}$ century. The greatest threat to the use of antibiotics is the emergence and spread of resistance in pathogenic bacteria that consequently cannot be treated by previously successful regimens [16].

Extended-spectrum $\beta$-lactamases in gramnegative pathogens have been implicated as enzymes responsible for resistance to $\beta$-lactam antibiotics such as ceftazidime and aztreonam [17]. Initially these enzymes were identified in isolates in Western Europe, where major outbreaks of ceftazidime resistant members of the family Enterobacteriaceae have been described, particularly involving Klebsiella pneumoniae [18]. Enterobacter species, in particular, Enterobacter cloacae and Enterobacter aerogenes are able to compromise 
antibacterial treatment by over expressing the chromosomal AmpC beta lactamase [19]. Emergence and spread of Class A extendedspectrum beta-lactamases (ESBLs) among these species are further complications [20].

The extended spectrum $\beta$-lactamases have been identified most often among strains of Klebsiella pneumoniae responsible for outbreaks of nosocomial infections particularly in intensive care units but also in oncology units and chronic care facilities [21]. This investigation was designed to isolate and characterize some multidrug resistant nosocomial bacteria from two hospitals environment at Damietta.

\section{Materials and methods}

\section{Sites of samples collection}

Sixty swab samples were obtained from various items in the wards and staff apparels of two selected hospitals in Damietta Governorates; these include Kafr Saad General Hospital and ElAzhar University Teaching Hospital (30 samples from each hospital). The items from which the samples were collected include sink, floor, bed, bed cover, toilet floor, bed pan, ward wall and hospital staff apparel (protective gowns, hand groves and face-shield) within reception hall, maternity ward, convalescing wards, surgical theaters, intensive care, dental unit, pharmacy and laboratory of each hospital.

Sterile swab tubes each containing prepared Cled broth were labeled appropriately and were taken to the hospital. Swabbing of the surface of each item was made using sterile cotton wool soaked with Cled broth. Many portions as possible of each item were swabbed and more than one swab stick was used for each subject. The swabs were inoculated into each labeled tube and covered. All the samples were immediately conveyed to the laboratory for processing [22].

\section{Antibiogram (antibiotic sensitivity test)}

Antibiotic susceptibility of the bacteria isolates was assayed according to the disc diffusion method [23]. Few colonies of each bacterial isolates were picked with a wire loop from the original culture plate and introduced in to test tubes containing $4 \mathrm{ml}$ of nutrient broth medium. The tubes were incubated for 3 to 4 hours at $37^{\circ} \mathrm{C}$. Petri dishes $9 \mathrm{~cm}$ were used with cled agar, plates were dried for about $30 \mathrm{~min}$ before incubation. Each bacterial broth suspension was streaked evenly in three planes into the surface of the medium with a sterilize cotton swab. After the inoculum was dried, standard commercial paper discs containing known amounts of the selected antibiotics (Trimethoprim/ sulphamethoxazole $(25 \mu \mathrm{g})$; Rifampicin $(5 \mu \mathrm{g})$; Piperacillin/tazobactam $(110 \mu \mathrm{g})$; Ofloxacin (5 $\mu \mathrm{g})$; Nitrofurantoin $(300 \mu \mathrm{g})$; Imipenem $(10 \mu \mathrm{g})$; Gentamicin $(120 \mu \mathrm{g})$; Ceftriaxone $(30 \mu \mathrm{g})$; Cefotaxime $(30 \mu \mathrm{g})$; Amikacin $(30 \mu \mathrm{g})$ and Amoxicillin/clavulanic acid $(30 \mu \mathrm{g})$ were gently passed down with flamed forceps to ensure contact and the plates were kept in refrigerator at $4{ }^{\circ} \mathrm{C}$ for 1-2 hour, then the plates were incubated at $37^{\circ} \mathrm{C}$ for 24 hour. After the incubation, inhibition zone around each disc was measured for each disc and used to classify the organisms as sensitive or resistant to an antibiotic according to the interpretive standard of the clinical and laboratory standards institute [24]. The bacterial isolates were designated Sensitive (S), Intermediate (I) or Resistant (R).

\section{Morphological and biochemical characteristics}

Colonial characters, Microscopic examination of bacterial isolates (Gram and Endospore stain), Motility test, Biochemical test: Catalase test [25]. Coagulase tests [26]; Urease Test [27]; Triple sugar iron (TSI) test [28]; Oxidase test [29]; Methyl red test (MR); Voges Proskauer test; Citrate utilization test [30] and Reduction of nitrates. The bacterial isolates were identified by the following bacterial key $[30,31]$.

\section{Extraction of DNA and PCR amplification}

The bacterial genomic DNA extraction from bacterial cells was carried out using DNA purification kit (QIAGEN) according to manufacturer's instructions.

The universal Primers F (5'AGAGTTTGATCCTGGCTCAG-3') and R (5'AACGAGGTGATCCAGCC-3'), corresponding to the polymorphic region of bacterial $16 \mathrm{~S}$ rRNA [32] were used to amplify the $16 \mathrm{~S}$ rRNA gene. Briefly, $1 \mu \mathrm{l}$ of the forward and reverse primers was added to $2.5 \mu 1$ Taq polymerase buffer $10 \mathrm{x}$ (Promega, Madison, USA) containing a final concentration of $1 \mathrm{mM} \mathrm{MgCl} 2,0.2 \mathrm{mM}$ dNTPs and $0.2 \mu \mathrm{l}$ Taq polymerase $(5 \mathrm{U} / \mu \mathrm{l})$ in a final reaction volume of $25 \mu \mathrm{l}$. PCR reaction conditions were initial denaturation at $95^{\circ} \mathrm{C}$ for 5 min, 34 cycles at $95^{\circ} \mathrm{C}$ for $1 \mathrm{~min}, 60^{\circ} \mathrm{C}$ for $1 \mathrm{~min}$ 
and $72^{\circ} \mathrm{C}$ for $1 \mathrm{~min}$. Final extension at $72^{\circ} \mathrm{C}$ for 10 min was done. The results were visualized on $1.5 \%$ agarose gel stained by ethidium bromide and photographed using gel documentation system.

The amplified PCR products were sequenced using forward primer. Sequencing was performed using $\quad$ BigDye $^{\circledR} \quad$ Terminator v3.1 Cycle Sequencing kit (Applied Biosystems, Foster City, CA, USA) and model 3130xl Genetic Analyzer (Applied Biosystems, Foster City, CA, USA).

\section{Alignment and phylogenetic analysis}

Blast was performed to obtain the DNA sequence match with the best similarities with other related16S rRNA genes on database. Pair wise and multiple DNA sequence alignment were carried out using CLUSTALW multiple sequence alignment programme version 1.82 [33]. Bootstrap neighbour joining tree was generated using MEGA version 4 [34]. The Streptomyces coelicolor was used as an outgroup strain.

\section{Results}

Sixty clinical site swabs were collected from various items of Kafr Saad General Hospital and El-Azhar University Teaching Hospital and investigated. From the 60 sites swabs processed, $37(61.2 \%)$ swabs yielded at least one bacterial isolate and the remaining $23(38.8 \%)$ swabs did not yield any bacterial growth. Direct gram stain recovered 206 organisms from the swabs in the form of bacilli, cocci or a mixture of the two. The bacterial isolates were cultured on specific media and observed as the most frequent and were given serial code numbers.

Based on the morphological characterization (Table 1) and some specific biochemical reactions (Table 2) of the most resistant, intermediate and sensitive bacteria, the isolates were identified as Bacillus subtilis, Bacillus cereus, Enterobacter aerogenes and Klebsiella pneumoniae.

The results of this study indicated that most of the isolated bacterial strains (Table 3) are susceptible to most the tested antibiotics. From the results it was observed that Bacillus subtilis (the most resistant isolate) was resistance to Amoxicillin/clavulanic acid (30 $\mu \mathrm{g})$, Cefotaxime $(30 \mu \mathrm{g})$; Ceftriaxone $(30 \mu \mathrm{g})$; Nitrofurantoin (300 $\mu \mathrm{g}$ ); Rifampicin (30 $\mu \mathrm{g}$ ) and Trimethoprim/ Sulphamethoxazole $(1.25 \mu \mathrm{g}) \quad$ while, Enterobacter aerogenes and Klebsiella pneumoniae (intermediate isolates) showed resistance toward Amoxicillin/ clavulanic acid $(30 \mu \mathrm{g})$, Cefotaxime $(30 \mu \mathrm{g})$ and Ceftriaxone (30 $\mu \mathrm{g})$, Nitrofurantoin $(300 \mu \mathrm{g})$, respectively. On the other hand, Bacillus cereus (the most sensitive isolate) was appeared to be sensitive to all tested antibiotics.

Table 1. Morphological characteristics of the most resistant, intermediate and sensitive clinical bacterial isolate.

\begin{tabular}{|c|c|c|c|c|}
\hline \multirow{2}{*}{$\begin{array}{l}\text { Microscopy and } \\
\text { cultural characters }\end{array}$} & \multicolumn{4}{|c|}{ Reactivity* } \\
\hline & $\begin{array}{l}\text { Bacillus } \\
\text { subtilis }\end{array}$ & $\begin{array}{l}\text { Bacillus } \\
\text { cereus }\end{array}$ & $\begin{array}{l}\text { Enterobacter } \\
\text { aerogenes }\end{array}$ & $\begin{array}{l}\text { Klebsiella } \\
\text { pneumoniae }\end{array}$ \\
\hline Gram Stain & + ve & $+\mathrm{ve}$ & - ve & -ve \\
\hline Shape & Rods & Rods & Rods & Rods \\
\hline Spore formation & + ve & + ve & - ve & - ve \\
\hline $\begin{array}{l}\text { Pigmentation on cled } \\
\text { agar media }\end{array}$ & $\begin{array}{l}\text { Forming a } \\
\text { green pigment }\end{array}$ & $\begin{array}{l}\text { Forming a } \\
\text { white pigment }\end{array}$ & $\begin{array}{l}\text { Forming a } \\
\text { yellow pigment }\end{array}$ & $\begin{array}{l}\text { Forming a } \\
\text { green pigment }\end{array}$ \\
\hline Growth on cled agar media & $\begin{array}{l}\text { Grow on cled } \\
\text { medium, circular; } \\
\text { opaque; regular; } \\
\text { glistening and } \\
\text { convex }\end{array}$ & $\begin{array}{l}\text { Grow on nutrient } \\
\text { medium, circular; } \\
\text { opaque; regular; } \\
\text { and convex }\end{array}$ & $\begin{array}{l}\text { Grow on Cled } \\
\text { medium, circular; } \\
\text { opaque; regular; } \\
\text { glistening and } \\
\text { convex }\end{array}$ & $\begin{array}{l}\text { Grow on nutrient } \\
\text { medium, circular; } \\
\text { opaque; regular; } \\
\text { glistening and } \\
\text { convex }\end{array}$ \\
\hline $\begin{array}{l}\text { Growth on MacConkey's } \\
\text { agar media }\end{array}$ & $\begin{array}{l}\text { No formation of } \\
\text { pink colony (-ve) }\end{array}$ & $\begin{array}{l}\text { No formation of } \\
\text { pink colony (-ve) }\end{array}$ & $\begin{array}{l}\text { No formation of } \\
\text { pink colony }(+\mathrm{ve})\end{array}$ & $\begin{array}{l}\text { No formation of } \\
\text { pink colony }(+\mathrm{ve})\end{array}$ \\
\hline Haemolysis on blood agar & - ve & - ve & $\alpha$-haemolysis (green) & - ve \\
\hline $\begin{array}{l}\text { Triple Sugar Iron (TSI) } \\
\text { Agar }\end{array}$ & $\begin{array}{l}\text { Orange pink, } \\
\text { no black color }\end{array}$ & $\begin{array}{l}\text { Pink, } \\
\text { no black color }\end{array}$ & $\begin{array}{l}\text { Yellow, } \\
\text { no black color }\end{array}$ & $\begin{array}{l}\text { Yellow, } \\
\text { no black color }\end{array}$ \\
\hline
\end{tabular}

*+ve, positive - ve, negative 
Table 2. Biochemical reactions of the most resistant, intermediate and sensitive clinical bacterial isolate.

Biochemical Reactivity*
tests

\begin{tabular}{llll}
\hline $\begin{array}{l}\text { Bacillus } \\
\text { subtilis }\end{array}$ & $\begin{array}{l}\text { Bacillus } \\
\text { cereus }\end{array}$ & $\begin{array}{l}\text { Enterobacter } \\
\text { aerogenes }\end{array}$ & $\begin{array}{l}\text { Klebsiella } \\
\text { pneumoniae }\end{array}$ \\
\hline -ve & $-\mathrm{ve}$ & $-\mathrm{ve}$ & $-\mathrm{ve}$ \\
-ve & $-\mathrm{ve}$ & $+\mathrm{ve}$ & $+\mathrm{ve}$ \\
-ve & $+\mathrm{ve}$ & $-\mathrm{ve}$ & $-\mathrm{ve}$ \\
-ve & $+\mathrm{ve}$ & $-\mathrm{ve}$ & $+\mathrm{ve}$ \\
-ve & $-\mathrm{ve}$ & $-\mathrm{ve}$ & $-\mathrm{ve}$ \\
& & & \\
$+\mathrm{ve}$ & $+\mathrm{ve}$ & $-\mathrm{ve}$ & $+\mathrm{ve}$ \\
$+\mathrm{ve}$ & $+\mathrm{ve}$ & $+\mathrm{ve}$ & $+\mathrm{ve}$ \\
$-\mathrm{ve}$ & $+\mathrm{ve}$ & $-\mathrm{ve}$ & $-\mathrm{ve}$ \\
$+\mathrm{ve}$ & $+\mathrm{ve}$ & $+\mathrm{ve}$ & $+\mathrm{ve}$ \\
$+\mathrm{ve}$ & $+\mathrm{ve}$ & $-\mathrm{ve}$ & $-\mathrm{ve}$ \\
$+\mathrm{ve}$ & $+\mathrm{ve}$ & $+\mathrm{ve}$ & $+\mathrm{ve}$ \\
$+\mathrm{ve}$ & $+\mathrm{ve}$ & $-\mathrm{ve}$ & $-\mathrm{ve}$ \\
& & & \\
$+\mathrm{ve}$ & $+\mathrm{ve}$ & $+\mathrm{ve}$ & $+\mathrm{ve}$ \\
$+\mathrm{ve}$ & $+\mathrm{ve}$ & $+\mathrm{ve}$ & $+\mathrm{ve}$ \\
$-\mathrm{ve} w i t h$ & $+\mathrm{ve}$ & $-\mathrm{ve}$ & $+\mathrm{ve}$ with \\
pigmentation & & & pigmentation \\
$-\mathrm{ve}$ & $-\mathrm{ve}$ & $-\mathrm{ve}$ & $-\mathrm{ve}$
\end{tabular}

Phenylalanine

Oxidase test

Lactose Fermentation

Indole test

Urease test

$\mathrm{H} 2 \mathrm{~S}$ production Confirmatory tests

Catalase test

Voges-Proskauer

Methyl Red

Citrate utilization

Casein Hydrolysis

Starch Hydrolysis

Gelatin Liquefaction Nitrate reduction

Nitrite

Ammonia

Tyrosine Hydrolysis

determination

Utilization of sugars

Salicin

Glycerol

D-Xylose

L-Arabinose

D-Mannitol

D-Glucose

Maltose

Rhamnose

Galactose

Mannose

Fructose

Trehalose

Myo-Inositol

Sucrose

Sorbose

Acid from Gulcose

-ve
-ve
+ve
+ve
+ve
+ve
+ve
-ve
-ve
-ve
+ve
-ve
$+v e$
$+v e$
-ve
+ve

* + ve, positive - ve, negative

PCR amplicon with specific forward 16S rRNA primers of the four bacterial isolates were subjected to DNA sequence analysis. Data showed that 663 bp was obtained for Bacillus subtilis, $660 \mathrm{bp}$ for Bacillus cereus, $597 \mathrm{bp}$ for Enterobacter aerugenes and $764 \quad b p$ for Klebsiella pneumoniae isolates.
BLAST homology search for the resulted sequences of the four isolates revealed that, Bacillus subtilis isolate possessed $99 \%$ identity with other strains of Bacillus subtilis, Bacillus subtilis subsp. subtilis, Bacillus subtilis subsp. spizizenii, Bacillus subtilis subsp. inaquosorum, Bacillus sp, Bacillus tequilensis, Bacillus 
amyloliquefaciens and Bacillus methylotrophicus. The Bacillus cereus isolate is identical with strains of other Bacillus cereus, Bacillus sp., Bacillus thuringiensis and Bacillus anthracis by $100 \%$ identity. Also, Klebsiella pneumoniae isolate possessed $100 \%$ identity with other strains of Klebsiella pneumoniae, Klebsiella pneumoniae subsp. pneumoniae, Klebsiella pneumoniae subsp. rhinoscleromatis,
Klebsiella sp., Klebsiella varicola and Klebsiella rhinoscleromatis. The Enterobacter isolate showed $99 \%$ identity with other members of Enterobacteriales species such as Enterobacter hormaechei, Enterobacter ludwigii and Enterobacter cloacae, Enterobacter cancerogenus. The similarity distance between the four isolates and other related strains was represented as a phylogenetic tree (Fig. 1).

Table 3. Antibiotic susceptibility profile (sensitivity test) of clinical bacterial isolates against different antibiotics drugs.

\begin{tabular}{llccc}
\hline No. of Bacterial isolates & \multicolumn{3}{c}{ Antibiotic drugs } \\
\cline { 2 - 5 } & $\begin{array}{l}\text { Bacillus } \\
\text { subtilis }\end{array}$ & $\begin{array}{l}\text { Bacillus } \\
\text { cereus }\end{array}$ & $\begin{array}{l}\text { Enterobacter } \\
\text { aerogenes }\end{array}$ & $\begin{array}{l}\text { Klebsiella } \\
\text { pneumoniae }\end{array}$ \\
\hline Amikacin $(30 \mu \mathrm{g}) \mathrm{AK}^{*}$ & $17 \mathrm{~S}$ & $33 \mathrm{~S}$ & $28 \mathrm{~S}$ & $25 \mathrm{~S}$ \\
Amoxicillin/clavulanic acid $(30 \mu \mathrm{g}) \mathrm{AMC}$ & $0 \mathrm{R}$ & $28 \mathrm{~S}$ & $12 \mathrm{R}$ & $15 \mathrm{I}$ \\
Cefotaxime $(30 \mu \mathrm{g}) \mathrm{CTX}$ & $0 \mathrm{R}$ & $28 \mathrm{~S}$ & $9 \mathrm{R}$ & $23 \mathrm{~S}$ \\
Ceftriaxone $(30 \mu \mathrm{g}) \mathrm{CRO}$ & $0 \mathrm{R}$ & $32 \mathrm{~S}$ & $17 \mathrm{I}$ & $8 \mathrm{R}$ \\
Centamicin $(10 \mu \mathrm{g}) \mathrm{CN}$ & $15 \mathrm{~S}$ & $34 \mathrm{~S}$ & $14 \mathrm{I}$ & $13 \mathrm{I}$ \\
Imipenem $(10 \mu \mathrm{g}) \mathrm{IPM}$ & $16 \mathrm{~S}$ & $70 \mathrm{~S}$ & $39 \mathrm{~S}$ & $14 \mathrm{I}$ \\
Nitrofurantoin $(300 \mu \mathrm{g}) \mathrm{F}$ & $0 \mathrm{R}$ & $24 \mathrm{~S}$ & $15 \mathrm{I}$ & $11 \mathrm{R}$ \\
Ofloxacin $(5 \mu \mathrm{g}) \mathrm{OFX}$ & $23 \mathrm{~S}$ & $48 \mathrm{~S}$ & $20 \mathrm{I}$ & $19 \mathrm{I}$ \\
Piperacillin/Tazobactam $(110 \mu \mathrm{g}) \mathrm{TPZ}$ & $22 \mathrm{~S}$ & $34 \mathrm{~S}$ & $28 \mathrm{~S}$ & $31 \mathrm{~S}$ \\
Rifampicin $(30 \mu \mathrm{g}) \mathrm{RD}$ & $2 \mathrm{R}$ & $30 \mathrm{~S}$ & $18 \mathrm{I}$ & $19 \mathrm{I}$ \\
Trimethoprim/ Sulphamethoxazole $(1.25 \mu \mathrm{g}) \mathrm{SXT}$ & $0 \mathrm{R}$ & $33 \mathrm{~S}$ & $14 \mathrm{I}$ & $13 \mathrm{I}$ \\
\end{tabular}

* Abbreviation of the antibiotics; Diameters of inhibition zone in millimeter; R: Resistant; S: Susceptible and I: Intermediate

\section{Discussion}

Nosocomial infections occur worldwide and affect both developed and developing countries [35]. Many of these infections are associated with microorganisms that are resistant to antibiotics and can easily spread by hospital personnel [36]. Guidelines for antibiotic therapy can be helpful for clinicians to select more appropriate antibiotics for effective treatment and prevent the development of drug resistance [22]. This study shows the distribution of antibiotic resistance of bacterial species associated with nosocomial infections at a hospital in Damietta, Egypt, and this showed that they have become multi-resistant to these therapeutic agents, thus rendering these drugs ineffective as treatments of choice for infections caused by these pathogens.

Antibiotic resistance is a problem that continues to challenge the healthcare sector. Furthermore, in developing countries drugs are available to the public and thus people may practice self - administration of antibiotics and further increase the prevalence of drug resistant strains [37].

From the antibiotic susceptibility profile of the bacterial isolates, four strains labeled and identified as Bacillus subtilis, Bacillus cereus, Enterobacter aerogenes and Klebsiella pneumoniae were selected as most resistant, most sensitive and two intermediates, respectively.

The result of this study is consistent with Jalalpoor and Ebadi [38] who reported Bacillus species was the most frequent bacteria isolated in hospital environment followed by Enterobacteriace. Also this result correlates with the previous study on bacterial epidemiology in hospitals, where Bacillus species and Staphylococcus species were the major bacteria that were isolated from the hospital environment [39]. 


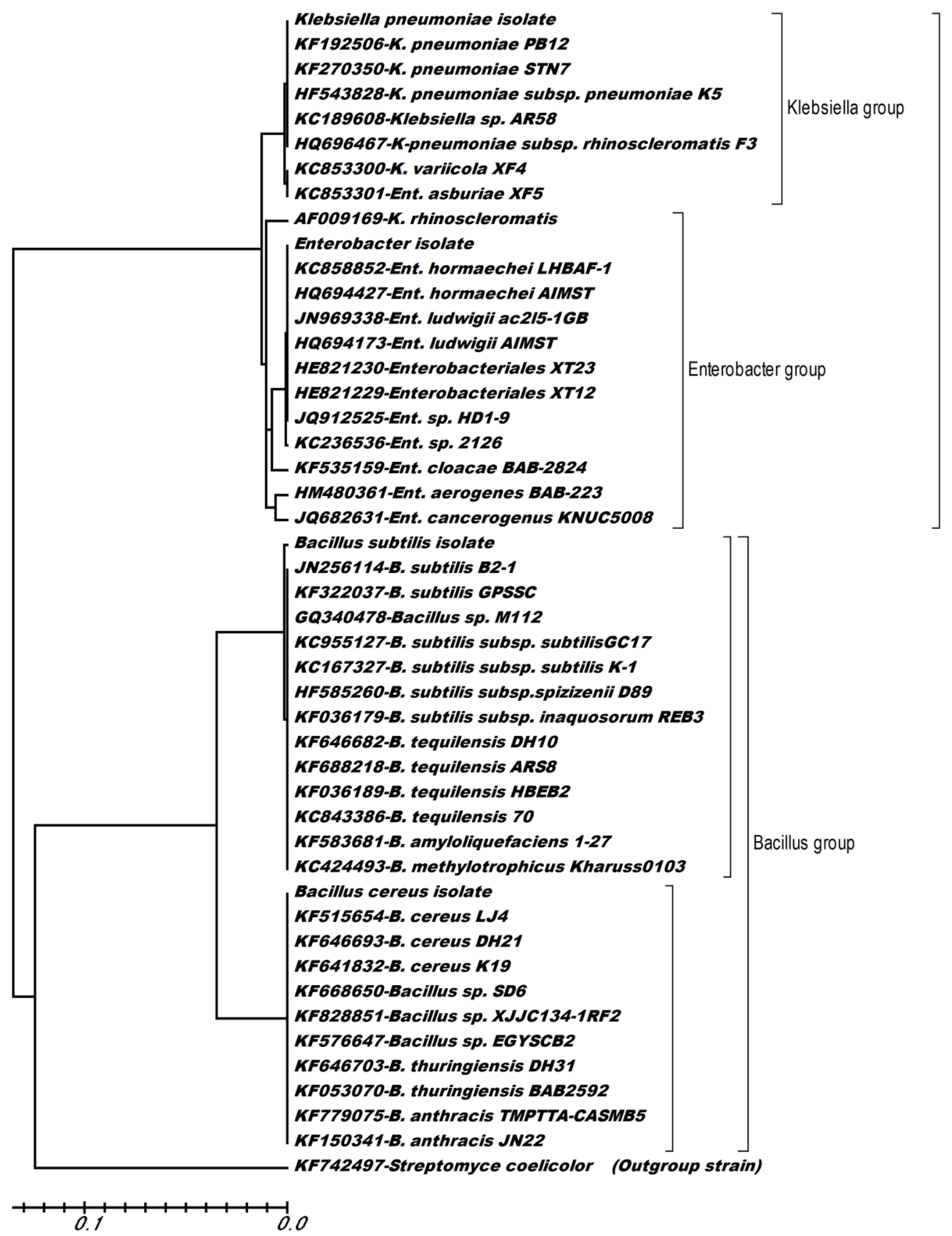

Fig. 1. Phylogenetic tree analysis based on the 16S rDNA sequence alignment for Klebsiella pneumoniae, Enterobacter aerogenes, Bacillus subtilis and Bacillus cereus with some other related members which possess the best similarity.

Nowadays, about $70 \%$ of bacteria causing infections in hospitals are resistant to at least one of the drugs most commonly used for treatment.
Imipenem has proved to have a broad spectrum and high activity against all the selected Gram positive and Gram negative bacterial isolates. 
These results are in accordance with data reported in previous studies of Tohamy et al. [41]. Moreover, the entire organisms showed higher resistance to Amoxicillin/clavulanate except Bacillus cereus. This finding is similar to the work of Muhammad et al. [22] who recorded higher resistance of Amoxicillin/clavulanate among both gram negative and Staphylococcus aureus. Enterobacteriaceae isolates resistant to multiple antibiotics have also been reported from several parts in the world [42].

The 16S rRNA sequence analysis confirmed the classical identification of the four isolated strains as they possessed a very high identity reach to $99-100 \%$.

In spite of Bacillus subtilis isolate showed 99\% identity with Bacillus tequilensis, Bacillus amyloliquefaciens and Bacillus methylotrophicus and other Bacillus subtilis strains, the classical biochemical tests were more related to Bacillus subtilis. The Bacillus cereus isolate is identical with strains of Bacillus thuringiensis, Bacillus anthracis and other strains of Bacillus subtilis by $100 \%$ identity, but the classical biochemical tests forced us to identify it as Bacillus cereus. Also, Klebsiella pneumoniae isolate which possessed $100 \%$ identity with other strains of Klebsiella pneumonia, Klebsiella varicola and Klebsiella rhinoscleromatis, the classical biochemical identification suggested to name it as Klebsiella pneumoniae. The species of Enterobacter isolate is named aerogenes according to the classical biochemical tests, although it showed $99 \%$ identity with Enterobacter hormaechei, Enterobacter ludwigii Enterobacter cloacae, Enterobacter cancerogenus and other Enterobacter aerogenes strains.

The antibiotic susceptibility results of the four bacterial isolates showed that, these organisms have been well exposed to the tested antimicrobials and they have developed mechanisms to evade or avoid these antibiotics which full agreement with Celik et al. [2]. Because of the prevalent of multiple antibiotic resistant bacteria search for new antibiotics effective against multi-drug resistant pathogenic bacteria is presently an important area of antibiotic research.

\section{References}

[1] M.A. Sarac, M. Baysallar, H. Gun, Nosocomial uropathogens and their antibiotic susceptibilities in a Turkish Military Hospital: a prospective and microbiological study. Turkish J. Med. Sci. 29 (1999) 165-168

[2] I. Celik, N. Inci, A. Denk, E. Sevim, D. Yasar, M. Yasar, Prevalence of Hospital acquired infections in Anesthesiology intensive care unit. Firat Tıp Dergisi 10 (2005) 132- 135

[3] Q. Nguyen, Hospital-Acquired Infections, Medicine from WEBMD Emedicine, New York, NY, USA (2004)

[4] B.E. Cleven, M. Palka-Santini, J. Gielen, S. Meembor, M. Kronke, O. Krut, Identification and characterization of bacterial pathogens causing bloodstream infections by DNA microarray. Clinic. Microbiol. 44 (2006) 23892397

[5] A. Jain, A. Awasthi, M. Kumar, Etiological and antimicrobial susceptibility profile of nosocomial blood stream infections in neonatal intensive care unit. Indian Medical Microbiology, 25 (2007) 299-300

[6] S.E. Coffin, T.E. Zaoutis, Infection control, hospital epidemiology and patient safety. Infect. Dis. Clin. Am. 19 (2005) 647-665

[7] M.J. Schwaber, C.S. Graham, B.E. Sands, H.S. Gold, Y. Carmeli, Treatment with a broadspectrum cephalosporin versus piperacillintazobactam and the risk for isolation of broad-spectrum cephalosporinresistant Enterobacter species. Antimicrob. Agents Chemother. 47 (2003) 1882- 1886

[8] J.W. Chow, M.J Fine, D.M. Shlaes, J.P. Quinn, D.C. Hooper, M.P. Johnson, R. Ramphal, M.M. Wagener, D.K. Miyashiro, V.L. Yu, Enterobacter bacteremia: clinical features and emergence of antibiotic resistance during therapy. Ann. Internatl Med. 115 (1991) 585-590

[9] P. Nordmann, L. Poirel, Emerging carbapenemases in gram negative aerobes. Clin. Microbiol. Infect. 8 (2002) 321-331

[10] F.A. Drobniewski, Bacillus cereus and related species. Clin. Microbiol. Rev. 6 (1993) 324-338

[11] P.Y. Liu, S.C. Ke, S.L. Chen, Use of pulsed-field gel electrophoresis to investigate a pseudooutbreak of Bacillus cereus in a pediatric unit. J. Clin. Microbiol. 35 (1997) 1533-1535

[12] E.A. Bryce, J.A. Smith, M.B. Tweeddale, J. Andruschak, M.R. Maxwell, Dissemination of Bacillus cereus in an intensive care unit. Infect. Control Hosp. Epidemiol. 14 (1993) 459-462

[13] F. Kunst, N. Ogasawara, I. Moszer, A. Albertini, M., G. Alloni, V. Azevedo, M. Bertero, G. Bessieres, P. Bolotin, The complete genome sequence of the Gram-positive bacterium Bacillus subtilis. Nature 390 (1997) 249-256

[14] M.O. Musa, M. Al Douri, S. Khan, T. Shafi, A. Humaidh, A.M. Rasheed, Fulminant septicaemic syndrome of Bacillus cereus: three case reports. J. Infect. 39 (1999) 154-156

[15] T. Das, K. Cloudhury, S. Sharma, S. Jalali, R. 
Nuthethi, Clinical profile and outcome in Bacillus endophthalmitis. Endophthalmitis Research Group. Ophthalmology 108 (2001) 1819-25

[16] A.S. Bolaji, I.O. Akande, F.A. Iromini, S.O. Adewoye, O.A. Opasola, Antibiotic resistance pattern of bacteria spp isolated from hospital waste water in Ede South Western, Nigeria. Europ. Exp. Biol. 1 (2011) 66-71

[17] G.A. Jacoby, A.A. Medeiros, More extendedspectrum, B-lactamases. Antimicrob. Agents Chemother. 35 (1991) 1697-1704

[18] C., de Champs, C. Sirot, M.C. Chanal, M. Poupart, P. Dumas, J. Sirot, Concomitant dissemination of three extendedspectrum $\beta$ lactamases among different Enterobacteriaceae isolated in a French hospital. J. Antimicrob. Chemother. 27 (1991) 441-457

[19] M.A. Pfaller, R.N. Jones, S.A. Marshall, S.L. Coffman, R.J. Hollis, M.B. Edmond, R.P. Wenzel, Inducible amp $\mathrm{C}$ beta-lactamase producing gram-negative bacilli from blood stream infections: frequency, antimicrobial susceptibility, and molecular epidemiology in a national surveillance program (SCOPE). Diagn. Microbiol. Infect. Dis. 28 (1997) 211-219.

[20] E. Tzelepi, P. Giakkoupi, D. Sofianou, V. Loukova, A. Kemeroglou, A. Tsakris, Detection of extended-spectrum beta lactamases in clinical isolates of Enterobacter cloacae and Enterobacter aerogenes. J. Clin. Microbiol. 38 (2000) 542-546

[21] G. Arlet, M.J. Sanson-Le Pors, M. Rouveau, G. Fournier, B. Schlemmer, A. Philippon, Outbreak of nosocomial infections due to Kiebsiella pneumoniae producing SHV-4 1-lactamase. Eur. J. Clin. Microbiol. Infect. Dis. 9 (1999) 797- 803

[22] U.K. Muhammad, A.I. Mustafa, A.Z. Musa, Antimicrobial resistance pattern of pathogenic bacteria isolated from four hospital environment in Sokoto Metropolis, Northwestern, Nigeria. J. Microbiol. Biotech. Res. 3 (2013) 120-124

[23] A.W. Bauer, W.M. Kirby, J.C. Sherris, M. Turk, Antibiotics susceptibility testing by standardized single disc method. Am. J. Clin. Pathol. 45 (1986) 493-496

[24] Clinical and Laboratory Standards Institute, Performance standards for antimicrobial disk susceptibility test. approved standards, M2-A8. $8^{\text {th }}$ ed, Wayne (PA) (2003)

[25] G.J. Cappuccino, N. Sherman, Biochemical activities of microorganisms, microbiology a laboratory manual. $6^{\text {th }}$ ed, 5 (2001) 133-194

[26] M. Cheesbrough, Microbiological test. In: Cheesbrough, M. (ed). District laboratory practice in tropical countries, (2000). pp. 1-226. Cambridge university press, UK

[27] K.J.D. Wolfgang, P. Hilda, A.D. Brrnard, M. Catherine, Oral microbiology. In Zinsser microbial. $20^{\text {th }}$ edition. Editorial panarnericana publishing (1998)

[28] E.W Koneman, S.D. Allen, W.A. Janda, Guideliness for the collection transport, processing, analysis and reporting of cultures from specific specimen sources. In: Koneman, E. W, Allen, S. D., Janda, W. A., Schrekenberger, p. C. and text book of diagnostic. Microbiology, 121-162. Lipoincott Raven, Washington (1997)

[29] A. L. Smith, Laboratory identification in microbiology and pathology. $12^{\text {th }}$ ed. The C.V. Moby company st. Lovies. Toronto. London, 68 (1980)

[30] J.G. Collee, W. Marr, A.G. Fraser, B.P. Mormion, A. Simmons, Specimen collection, culture containers and media: Mackie and Macarthey practical medical microbiology. Churchilli Livingstone, New York, London, Tokyo (1996) 95-111

[31] Bergey's Manual of Systematic Bacteriology, The Alpha-, Beta-, Delta-, and Epsilon proteobacteria. Garrity, G., Brenner, D. J., Krieg, N. R., Stanley, J. T. (eds.) Springer-Verlag, New York. (2005)

[32] J. Sambrook, D.W. Russell, In vitro amplification of DNA by the polymerase chain reaction. In: Molecular cloning: a laboratory manual, $3^{\text {rd }}$ ed., Cold Spring Harbor Laboratory, New York (2001) 113

[33] J.D. Thompson, D.G. Higgins, T.J. Gibson, CLUSTAL W: improving the sensitivity of progressive multiple sequence alignment through sequence weighting, position-specific gap penalties and weight matrix choice. Nucleic Acids Res. 22 (1994) 4673-4680

[34] K. Tamura, J. Dudley, M. Nei, S. Kumar, MEGA4: Molecular Evolutionary Genetics Analysis (MEGA) software version 4.0. Mol. Biol. Evol. 24 (2007) 1596-1599

[35] World Health Organization (WHO), Prevention of Hospital-Acquired Infections. A Practical Guide, WHO Press, Geneva, Switzerland, $2^{\text {nd }}$ edition (2002)

[36] B. Durmaz, R. Durmaz, B. Otlu, E. Sonmez, Nosocomial infections in a new medical center, Turkey. Infect. Cont. Hosp. Epidemiol. 21 (2000) 534-536

[37] D.W. Gerard, D.S. Arlene, New strategies for combating multi-drug-resistant bacteria, J. Clin. Microbiol. 13 (2007) 260-267

[38] S. Jalalpour, A.G. Ebadi, Afric. J. Pharm. Pharmacol 6 (2012) 108-112

[39] R.B. Nasiry, Overview of Bacterial in Operations room Environment in Hospitals Shahid Beheshty University. The 3th National Cong. of Microbiol. Iran-Hamedan (2000)

[40] E.Y. Tohamy, A.M. Abou Zeid, A.A. Shaheen, S.F. Elwadi, Nosocomial infection in Surgical hospital in Zagazig University. Arab Univ. Cairo 14 (2006) 133-145

[41] L.M. Hall, M. Blok, T. Donders, A. Paauw, A.C. 
Fluit, J. Verhoef, Multi-drug resistance among Enterobacteriacae is strongly associated with the presence of integrons and is independent of species or isolate origin. J. Infect. Dis. 187 (2003) 251-259

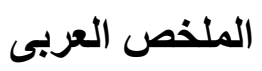

عزل وتعريف بعض الأجناس البكتيرية المقاومة للمضادات الحيوية والمرتبطة بعدوى المستثفيات

زكريا عوض بقا، محمد اسماعيل أبو دوبارة، أحمد قاسم عبد الصمد، شيماء عبدالحكيم بدوي قسم النبات ـ كلية الطوم - جامعة دمياط ـ مصر أحر

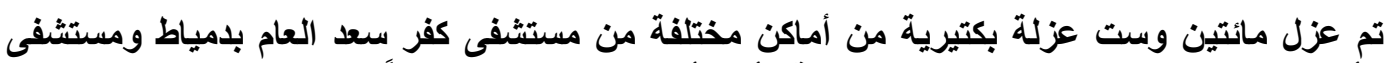

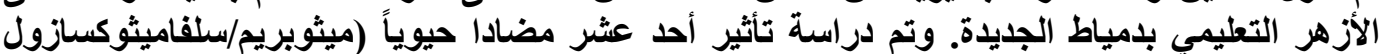

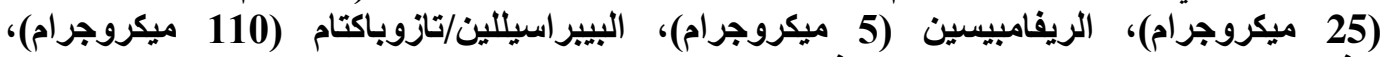

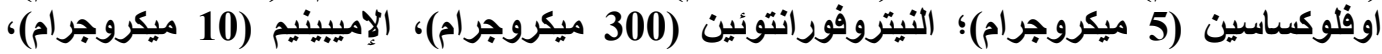

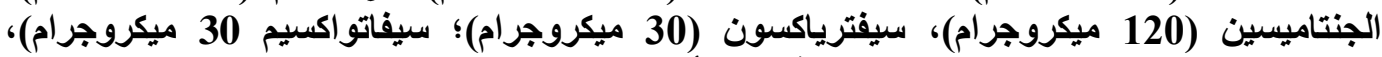

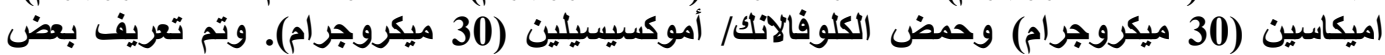

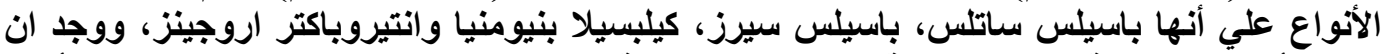

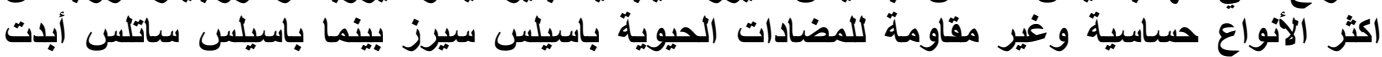

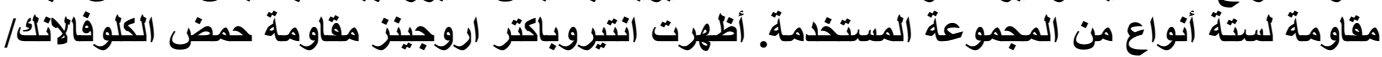
أموكسيسيلين وسيفاتو اكسيم، بينما أبدت كيلبسيلا بنيومنيا مقاومة سيفترياكسون و والنيتروفورانتونئين. 